Jesica Warzecha ${ }^{1}$

Uniwersytet Opolski

\title{
SPOŁECZNA ROLA PRACOWNIKA SOCJALNEGO: JEJ KSZTAŁTOWANIE I ODGRYWANIE W PERSPEKTYWIE DRAMATURGICZNEJ ERVINGA GOFFMANA
}

\author{
Abstract \\ The social role of social worker: its shaping and acting in Erving Goffman's dramaturgical \\ perspective
}

The subject of the work is shaping and playing the social role of a social worker in the dramaturgical perspective of Erving Goffman. The article is based on the author's own research carried out for the purposes of the BA thesis. A qualitative method was used, namely an in-depth interview and participant observation. The aim of the article is to describe and explain how the social role of a social worker is shaped and played in the light of Erving Goffman's dramatic concept on the basis of research carried out at the Municipal Social Welfare Center. Social workers and students of social work participated in the study. The main hypotheses adopted in this work are the assumptions that the social role of a social worker is shaped and played by participation in performances with a defined interactive order, and that each of the performances contains a defined interactive order to which certain, constant elements are subordinated. The collected data was analyzed using the Atlas.ti qualitative analysis software. The research shows that social workers shape and play their social role by preparing in the backstage and during performances on stages, which are: studies, internships and professional work both in the center and in the field.

Key words: social worker, social role, dramaturgical perspective, qualitative research

\section{Wprowadzenie}

Przedstawione w tym artykule wnioski są efektem badań jakościowych, przeprowadzonych na potrzeby rozprawy licencjackiej pod tytułem Konstruowanie tożsamości społecznej pracownika socjalnego, opublikowanej w 2019 roku na Uniwersytecie Opolskim pod

${ }^{1}$ Studentka studiów II stopnia na kierunku socjologia, Instytut Nauk Pedagogicznych UO. 
kierunkiem dr Magdaleny Piejko-Płonki. Inspiracją dla podjęcia tego tematu były obowiązkowe praktyki studenckie, które należy odbyć na drugim roku studiów I stopnia. To właśnie udział w nich oraz możliwość obserwowania pracy pracowników socjalnych był punktem wyjścia do podjęcia moich rozważań. Po kilku dniach spędzonych na praktykach chciałam wiedzieć coraz więcej o kobietach, z którymi pracowałam. $\mathrm{Z}$ zainteresowaniem słuchałam ich historii, rozmów między nimi oraz dialogów z petentami, jeśli tylko była taka możliwość. Po pewnym czasie zaczęłam się interesować instytucjonalną pomocą społeczną i zagłębiać w zakres obowiązków pracowników. Sprawdzałam możliwości, jakie posiadają, oraz zrobiłam pierwszy przegląd literatury na ten temat. Dotarłam do kilku publikacji, które podjęły temat tożsamości pracowników socjalnych. Jednak skupiały się one mocniej na analizie granic między interesentami a pracownikami socjalnymi lub też przedstawiały praktyczne wskazówki dotyczące pracy z petentami. Podejmowano również rozważania nad kształtowaniem tożsamości społecznej pracowników socjalnych. Postanowiłam rozwinąć tę myśl i zbadać problem. Chciałam się dowiedzieć, czy wspomniana wcześniej tożsamość ma charakter dynamiczny i w jaki sposób jest kształtowana. W niniejszej pracy chciałabym skupić się na jednym z szeregu podejmowanych w mojej pracy dyplomowej problemów i wyjaśnić, w jaki sposób kształtuje się i odgrywa społeczna rola pracownika socjalnego. Na podstawie koncepcji dramaturgicznej Goffmana zostały przyjęte następujące hipotezy:

- Społeczna rola pracownika socjalnego kształtowana i odgrywana jest przez udział $\mathrm{w}$ występach $\mathrm{z}$ ustalonym porządkiem interakcyjnym.

- Każdy z występów zawiera ustalony porządek interakcyjny, któremu podporządkowane są pewne, stałe elementy.

Jako ramę interpretacyjną swoich badań przyjęłam koncepcję dramaturgiczną Ervinga Goffmana. Autor posługuje się w niej głównie takim pojęciami, jak porządek interakcyjny, definicja sytuacji, występ, aktor społeczny, rola, publiczność, kulisy (Goffman 1981). Uważam, że metafora teatru idealnie odzwierciedla elementy aktywności pracowników socjalnych i za jej pomocą jestem w stanie pokazać, w jaki sposób jest kształtowana oraz odgrywana społeczna rola takiego pracownika. Koncepcja dramaturgiczna wywodzi się z interakcjonizmu symbolicznego, który przyjmuje, że społeczeństwo powstaje na skutek interakcji międzyludzkich. Nie jest ono czymś zastanym przez jednostkę. Kładzie się nacisk na świadome decyzje podejmowane przez jednostki, co jest charakterystyczne dla nurtu socjologii humanistycznej. Na podstawie ustaleń Goffmana przyjęłam założenie, że tożsamość pracowników socjalnych ma charakter dynamiczny - zmienia się i ewoluuje.

Celem niniejszego artykułu jest opisanie i wyjaśnienie, w jaki sposób kształtuje się i odgrywa społeczna rola pracownika socjalnego w świetle koncepcji dramaturgicznej Ervinga Goffmana na podstawie badań przeprowadzonych w Gminnym Ośrodku Pomocy Społecznej. 


\section{Metodologia badań własnych}

Badania jakościowe można prowadzić na wiele sposobów i posługując się różnymi metodami badawczymi. Ja wybrałam jedną z najbardziej podstawowych form gromadzenia informacji - metodę wywiadu. W przeprowadzonym badaniu zastosowałam technikę indywidualnego wywiadu, pogłębionego i kierowanego, opartego na dyspozycjach scenariusza wywiadu. Podczas rozmowy posługiwałam się wcześniej przygotowanym scenariuszem i zadając pytania, starałam się ukierunkowywać rozmowę na tematy związane z problemami badawczymi. W badaniach jakościowych realizowanych metodą wywiadu stosuje się celowy dobór próby, zwłaszcza w przypadku, gdy przyjmie się założenia interakcjonizmu symbolicznego. Wówczas celem badania jest zrozumienie symboli i znaczeń dotyczących badanego zjawiska, a nie jego statystyczny opis (Flick 2010). W trakcie badania przeprowadzono siedem wywiadów jakościowych, z czego cztery odbyły się z pracownicami socjalnymi, a kolejne trzy ze studentkami pracy socjalnej. Dobór próby okazał się dosyć trudnym zadaniem, ponieważ swoje badania ograniczyłam do jednego Gminnego Ośrodka Pomocy Społecznej na Opolszczyźnie, w którym zatrudnionych jest kilku pracowników i są to same kobiety. Pod uwagę brałam wszystkie pracownice, ale zgodę wyrazily cztery osoby. W przypadku studentów pracy socjalnej postanowiłam skorzystać z tak zwanej sieci kontaktów i metodą kuli śniegowej docierałam do kolejnych badanych. Udało mi się przeprowadzić trzy wywiady ze studentkami pracy socjalnej. W badaniu wzięły udział same kobiety. Jeśli kiedyś będę kontynuować swoje badania, to z całą pewnością chciałabym włączyć do próby mężczyzn, zarówno studentów pracy socjalnej, jak i praktykujących pracowników socjalnych. Opracowanie scenariusza było bardzo czasochłonne, ale i tak po każdym wywiadzie dyspozycje były modyfikowane. Najczęściej modyfikacja ta polegała na dodawaniu nowych kwestii, które pojawiły się w poprzedniej rozmowie. Przewidziany czas na realizację scenariusza to 60 minut, jednak w praktyce jego długość była różna. Najkrótszy wywiad zajął 31 minut, a najdłuższy 84 minuty. Przygotowałam dwa scenariusze, ponieważ postanowiłam dotrzeć zarówno do doświadczeń studentów pracy socjalnej, jak i aktywnych zawodowo pracowników socjalnych. Zdecydowałam się na włączenie studentów pracy socjalnej do próby, aby dowiedzieć się, jak odbywa się przygotowanie do roli pracownika socjalnego i jak ta rola się zmienia wraz z rozpoczęciem pracy w zawodzie. Scenariusz wywiadu ze studentami pracy socjalnej składał się z takich bloków tematycznych, jak:

- podjęcie i rozpoczęcie studiów na kierunku praca socjalna,

- praktyki zawodowe,

- plany po studiach i wyobrażenia na temat pracy pracownika socjalnego.

Wersja dla pracowników socjalnych została podzielona na dwa obszerne bloki tematyczne: studia oraz praca zawodowa. Wszystkie wywiady zostały zarejestrowane na dyktafonie w telefonie komórkowym, o czym respondentki zostały wcześniej poinformowane. Była to czynność niezbędna do wykonania transkrypcji, a następnie analizy danych. 
W swoim badaniu posłużyłam się również metodą uzupełniającą, a była to obserwacja, w ramach której zastosowano technikę obserwacji bezpośredniej uczestniczącej realizowanej również podczas obowiązkowych praktyk zawodowych w czasie studiów w Gminnym Ośrodku Pomocy Społecznej. Podczas badania kluczowe były dla mnie takie elementy, jak:

- wygląd oraz zachowanie pracowników socjalnych,

- wygląd ośrodka - jak wyglądały pomieszczenia i co się znajdowało na meblach,

- dyskusje podejmowane przez pracownice socjalne,

- interakcje między pracownikami a petentami pomocy społecznej.

Badanie rozpoczęło się we wrześniu 2018 roku, czyli w momencie, w którym udałam się na praktyki zawodowe do Gminnego Ośrodka Pomocy Społecznej i zaczęłam prowadzić pierwsze zapiski ze swoich obserwacji. Zakończeniem tego etapu działań była analiza danych wykonana w czerwcu 2019 roku. Analiza miała na celu sformułowanie odpowiedzi na postawione pytania badawcze i wspomagana była programem do analizy danych jakościowych Atlas.ti. Wykorzystane zostały procedury kodowania wstępnego i skoncentrowanego. Każdej badanej przyporządkowane zostały kody B1; B2; B3; B4; B5; B6 oraz B7, umieszczono je w nawiasie przy wypowiedzi uczestniczek wywiadu.

W przygotowaniach do przeprowadzenia badań terenowych bardzo przydatny okazał się Kodeks etyki socjologa, uchwalony 25 marca 2012 roku przez Walne Zgromadzenie Delegatów Polskiego Towarzystwa Socjologicznego. Składa się on z 46 punktów, które stanowią zwięzłe wskazówki dla badacza. Pokazuje, jakimi zasadami należy się kierować $\mathrm{w}$ trakcie procesu badawczego oraz uświadamia, jaka odpowiedzialność ciąży na osobie przeprowadzającej badanie. Przeprowadzona obserwacja postawiła również na mojej drodze kilka pytań etycznych, z którymi musiałam się zmierzyć. Przed rozpoczęciem badań wybrałam się do Ośrodka Pomocy Społecznej, w którym odbywałam praktyki, na rozmowę z kierowniczką. Zapoznałam ją z ogólnym celem badań oraz z faktem, że wywiady będą nagrywane. Następnie poprosiłam o zgodę na przeprowadzenie badań w placówce, którą zarządza. Po jej uzyskaniu przeprowadziłam rozmowy z pracownicami, aby uzyskać zgody również od nich. Po zaakceptowaniu mojej prośby umówiłam się z każdą z nich na indywidualny termin. Jednak pierwszym poważnym problemem była dla mnie kwestia podania nazwy miejscowości, w której znajduje się wyżej wspomniany Gminny Ośrodek Pomocy Społecznej. Ostatecznie zdecydowałam, że ze względu na poufność oraz możliwość zidentyfikowania respondentek nazwa miejscowości, w której znajduje się Ośrodek, pozostaje anonimowa.

\section{W świetle dramaturgicznej koncepcji Goffmana}

\section{Aktor społeczny - pracownik socjalny}

Analiza wypowiedzi respondentów została wykonana przez pryzmat goffmanowskiej koncepcji dramaturgicznej. W tej części artykułu chciałabym skupić się na opisie 
aktorów społecznych, którymi w głównej mierze są pracownicy socjalni. Pragnę również pokrótce scharakteryzować petentów pomocy społecznej, z którymi pracownicy wchodzą $\mathrm{w}$ różnego rodzaju interakcje.

W spektaklu rozgrywanym w Gminnym Ośrodku Pomocy Społecznej, w którym realizowane było badanie, $\mathrm{w}$ rolę pracowników socjalnych wcielają się wyłącznie kobiety. To one są aktorkami społecznymi naszego spektaklu. Na pytanie, czy płeć ma znaczenie w wykonywaniu zawodu pracownika socjalnego, odpowiadały następująco:

Na pewno mężczyzna byłby bardziej stanowczy i klienci, którzy są trudni we współpracy czuliby większy respekt przed mężczyzną. Ale z drugiej strony mi się wydaje, że to kobiety są takie bardziej opiekuńcze i wynajdą jeszcze, że w ten sposób można jeszcze pomóc, a jeszcze w ten. A może jeszcze coś innego zrobić dla tej rodziny. No ale szkoda, że jest tak mało mężczyzn, bo u nas, ani jednego (B3).

Inna badana wyjaśnia:

Z perspektywy czasu i obserwacji wydaje mi się, że kobiety są lepszymi pracownikami socjalnymi, niż mężczyźni. Kobiety przede wszystkim [patrzą - dop. J.W.] no przez pryzmat... Większość z nas ma własne dzieci, rodziny, problemy i gdzieś są bardziej wrażliwe, empatyczne. A mężczyźni raczej tak na chłodno do tego wszystkiego podchodzą (B2).

W pierwszym momencie badane stwierdziły, że płeć nie ma znaczenia, lecz uzasadniając swoją odpowiedź, opowiadają o tym, że to kobiety posiadają cechy potrzebne w pracy pracownika socjalnego. Według respondentek istnieje niepisana reguła, według której pewne zawody przypisane są określonej płci. Zawód pracownika socjalnego przypisuje się kobietom: „Ale raczej takie jakby osoby pierwszej pomocy to są z reguły kobiety” (B7). Jednak nie uważają, że mężczyzna byłby złym pracownikiem. Wręcz przeciwnie, mógłby wzbudzić respekt u trudnych klientów, ale niestety niewielu mężczyzn wykonuje ten zawód.

Odgrywając swoje role, pracownicy socjalni wchodzą w interakcje z inną, charakterystyczną i bardzo zróżnicowaną grupą aktorów, którą są petenci pomocy społecznej. Do Ośrodka przychodzą osoby skromne, potrzebujące, proszące nie tylko o pomoc finansową, ale także o wsparcie psychiczne. Są też petenci, którzy w Ośrodku pojawiają się regularnie, a ich zachowanie jest roszczeniowe, a nawet niegrzeczne. Nie chcą współpracować, unikają podjęcia pracy. Jedna z badanych w następujący sposób opisuje swoich petentów:

Chociaż ja osobiście nie ukrywam, że oczywiście nie faworyzujemy petentów, ale że mam takich których po prostu, no ja osobiście mogę powiedzieć z czystym sumieniem, że nie lubię ich. Bo nie są empatyczni, przychodzą roszczeniowo nastawieni. Tak naprawdę im jesteś milszy dla niego, tym jest gorszy dla Ciebie. Dlatego mówię no niektórzy są okropni. Ale mamy też kilka takich naprawdę fajnych osób, które mimo gdzieś swojej skromności, biedy, które przez lata prowadzą, 
żyją w nich, to są takimi ludźmi z krwi i kości. Mają gdzieś w sobie człowieczeństwo i empatię. A są też tacy, którzy przychodzą i bo on chce, bo jemu się należy, ale sam od siebie nic. No takich ludzi jest mi ciężko zrozumieć. Nie powiem, że ich jakoś gorzej traktuję, ale jestem mniej wyrozumiała wtedy dla nich (B2).

Powyższa wypowiedź charakteryzuje dwie skrajne grupy petentów, z którymi pracownicy socjalni wchodzą w interakcje. Nie zawsze są to sytuacje łatwe i przyjemne. Klienci potrafią być również trudnymi osobami, a pracownicy powinni umieć sobie radzić w takich sytuacjach. Z moich obserwacji wynika, że niezależnie od tego, do której grupy należą petenci to pracownice socjalne są zawsze optymistycznie nastawione i każdej osobie starają się znaleźć jak najwięcej możliwych rozwiązań wyjścia z ich sytuacji.

\section{Scenariusze - programy studiów, ustawy oraz doświadczenie innych pracowników}

Pierwszy scenariusz, który mają do dyspozycji pracownicy socjalni, to program studiów, gdzie zdobywana jest wiedza teoretyczna. Studenci pracy socjalnej od początku są przygotowywani na to, że będą pracować w zawodzie interdyscyplinarnym, zdobywają więc wiedzę z wielu dziedzin, oczywiście koncentrując się przy tym na pracy socjalnej:

Na pierwszym roku studiów były przedmioty ogólne, z różnych dziedzin. Był kurs z zakresu ekonomii, polityki, prawa, wprowadzenie do badań. W drugim semestrze pojawiło się więcej przedmiotów związanych z badaniami, a teraz jest też seminarium dyplomowe. Mamy również kursy kierunkowe, gdzie prowadzący podają nam jakieś tematy do wyboru, kursy pozakierunkowe oraz lektoraty (B5).

Następnie, gdy scenariusze studiów powinny zostać już dobrze przyswojone, pracownicy podczas wykonywania pracy korzystają z kolejnych. Na szczególną uwagę zasługuje często wspominana przez respondentki ustawa o pomocy społecznej, w której znajdują wszelkie wskazówki do codziennej aktywności zawodowej:

W sumie to ustawa o pomocy społecznej wszystko reguluje (B1).

Generalnie jest tak, że to Ustawa mówi nam, że na pięć tysięcy mieszkańców czy rodzin, ilu powinno być pracowników socjalnych. U nas jest pięć tysięcy mieszkańców z małym haczykiem, także musimy mieć dwóch pracowników socjalnych, którzy są w terenie i ten warunek spełniamy (B2).

Program studiów i ustawa to sformalizowane scenariusze, obejmujące wszystkich aktorów - studentów pracy socjalnej i pracowników socjalnych. Określają one zakres podstawowej wiedzy oraz, by użyć sformułowania Goffmana, fasady osobistej pracowników socjalnych. Dla pracownic niezwykle ważna jest obecność i wsparcie koleżanek. Świadomość, że zawsze mogą się poradzić jest dla nich bardzo istotna. Kobiety wiedzą, że nigdy nie zostaną same z danym problemem, tylko zawsze ktoś zaproponuje pomoc w jego rozwiązaniu. Uważam, że doświadczenie innych pracowników jest rodzajem 
niespisanych scenariuszy dla pracownic. Mogą otrzymać od koleżanek porady, jak rozwiązać daną sprawę, z którą na swojej ścieżce kariery się jeszcze nie spotkały. Pracownice uczą się czegoś nowego każdego dnia, a to jaką badana jest pracownicą socjalną może ulec modyfikacji na skutek interakcji z innymi pracownikami, tak wynika $\mathrm{z}$ wypowiedzi jednej z badanych:

I myślę, że to jest dobre, bo każda z nich ma swoje doświadczenie i swój pomysł na rozwiązanie danego problemu. Gdzie inna osoba by na to nie wpadła i to jest dobre, że można przyjść, wygadać się i znaleźć wspólne rozwiązanie. Bo tak naprawdę inne problemy, inne osoby i każdy może to gdzieś inaczej rozwiązać, każdy ma z tym styczność (B4).

Są tutaj pracownicy, którzy pracują tutaj po kilkadziesiąt lat i mają ogromne doświadczenie, na którym ja sama bazuję. Bo uważam, że ja się ciągle uczę (B2).

\section{Publiczność}

Z przeprowadzonych przeze mnie badań wynika, że w rolę publiczności najczęściej wcielają się rodzice. To oni są osobami, które skłaniały swoje dzieci do wyboru określonej ścieżki życiowej, pozostawiając im przy tym swobodę w podjęciu decyzji:

Yyy, zawsze moi rodzice mnie wspierali. I nawet jak była mowa, że może niekoniecznie bym poszła na studia. To zawsze było „rób coś co Ci się będzie podobało, coś co Ci się wydaje w czym się sprawdzisz, że to może być zawodówka” (B7).

\section{Kulisy - przygotowania do odgrywania roli pracownika socjalnego}

Kulisy są tym elementem koncepcji dramaturgicznej, który wskazuje, że odgrywanie roli społecznej poprzedzone jest wieloma przygotowaniami, w trakcie których aktorzy uczą się, w jaki sposób zbudować zaufanie, podtrzymywać fasadę oraz utrzymywać porządek interakcyjny. To kulisy decydują o tym, jak przebiegnie występ, dlatego pełnią istotną rolę w kształtowaniu i odgrywaniu roli pracownika socjalnego. Z przeprowadzonych badań wynika, że za kulisy można uznać okres od studiów przez czas praktyk zawodowych, aż do momentu zatrudnienia w ośrodku.

Jednym z ważniejszych okresów kulis to czas studiów, który jest teoretycznym przygotowaniem do wykonywania zawodu pracownika socjalnego. Tam poznaje się obowiązujące prawo, istniejące dokumenty i historię pomocy społecznej. Jednak respondentki narzekały, iż jest to sucha i wyuczona wiedza, na podstawie której trudno ocenić, na czym właściwie będzie polegał zawód pracownika socjalnego. Z pewnymi elementami pracy socjalnej badane spotkały się dopiero na praktykach zawodowych. Na przykład na studiach nie zapoznaje się studentów z dokumentami, z którymi później się pracuje. Studenci uczą się jedynie w teorii, czym jest dany dokument i kiedy go uźyć, ale nie pokazuje się studentom wzoru takiego dokumentu. Badane oceniają tę sytuację jako paradoksalną: 
Wydaje mi się, że powinno być więcej praktyki, mniej teorii. WIĘCEJ PRAKTYKI (B3). Studia to jest sucha wiedza (B2).

Bo studia to jest sama teoria. Wyuczone regułki, zasady postępowania (B6).

Bo to jest paradoksalne, ale przez 5 lat studiów nikt nam nie pokazał na żadnym przedmiocie, jak wygląda arkusz wywiadu środowiskowego, jak wygląda arkusz Niebieskiej Karty. Więc ja to wszystko dowiedziałam się dopiero na stażu (B3).

Studia jako kulisy są ważnym momentem, bo wówczas studenci zapoznają się z teoretycznymi podstawami zawodu i uzyskują dyplom, czyli potwierdzenie wiedzy oraz umiejętności potrzebnych do wykonywania zawodu pracownika socjalnego. Ale żeby móc w pełni przygotować się do występu na scenie, jaką będzie ośrodek pomocy społecznej, niezwykle ważne jest przejście przez kolejne kulisy, którymi są obowiązkowe praktyki zawodowe. To właśnie wtedy następuje skonfrontowanie wyobrażeń o pracy $\mathrm{z}$ zajęć na studiach z realiami funkcjonowania w tym zawodzie. Dla badanych jest to moment, kiedy „następuje weryfikacja tego, czego uczyliśmy się na studiach oraz czy chcemy iść tą drogą czy raczej będziemy od niej stronić” (B6). Dopiero na tym etapie studenci dowiadują się czym jest pomoc społeczna i na czym polega zawód pracownika socjalnego. W trakcie pierwszych praktyk studenci konfrontują się z tym, z czym i z kim będą musieli się zmierzyć w pracy:

Wydaje mi się, że dopiero jak zaczyna się pracować, ma się kontakt z tym wszystkim (B2).

No to jest taki sens studiów, bo ta wiedza taka teoretyczna nie daje nam tego wszystkiego, czego możemy się nauczyć tworząc te wszystkie przedsięwzięcia i działając. Myślę, że (praktyki) jest to bardziej cenny czas niż ta teoretyczna wiedza (B7).

Dowiedziałam się rzeczy zupełnie innych, niż uczyli na wykładach. Takich czysto praktycznych, nie ta cała teoria. Tylko jak to wygląda od środka (B3).

Jak już sugerowałam wcześniej, podczas praktyk zawodowych następuje weryfikacja planów związanych z wykonywaniem zawodu pracownika socjalnego:

Właśnie jeden kolega podczas praktyk stwierdził, że to nie jest całkowicie dla niego. Że już skończy studia ze względu na to, że to już prawie koniec. Ale też mam dziewczyny, które utwierdziły się w tym, że chcą wykonywać ten zawód (B5).

Z kulisami spotykamy się również w trakcie wykonywania zawodu pracownika socjalnego, w ośrodku pomocy społecznej. Pracownicy socjalni działają w ośrodku, ale również w terenie. Kulisy odgrywane są przed rozpoczęciem obu z tych typów pracy. Aby dobrze zaplanować swój czas w ośrodku niezbędne jest odpowiednie przygotowanie się i pracownicy robią to na kilka sposobów. Ważnym elementem każdego dnia jest organizacja ich pracy, gdy mogą omówić sobie dzień poprzedni, wymienić się historiami, skomentować je i wyciągnąć wnioski - na tej podstawie planują aktualny dzień. Jest to 
ważny dla nich moment, gdyż takie przygotowanie wyznacza kierunek pracy na następny dzień i pozwala uniknąć chaosu.

\begin{abstract}
Rano mamy przeważnie takie 30-40 minut organizacyjne, czyli opowiadamy sobie. Bo nie zawsze jesteśmy w stanie pod koniec dnia się zobaczyć, bo np. pracownicy socjalni są w terenie, zjeżdżają czasami po swoim czasie pracy (...) i wtedy omawiamy sobie dzień poprzedni. Czyli jak było u danych rodzin, co się działo, gdzie jakakolwiek pomoc jest potrzebna. Często gęsto jest tak, że jak już wieczorem słyszymy straż, policję, pogotowie to już do siebie piszemy, gdzie i co się dzieje, czy przypadkiem nie na naszym terenie, więc sobie gdzieś tam do 8:30 powiedzmy opowiadamy sobie te historie, kawa i planujemy sobie dzień (B2).
\end{abstract}

Wypowiedź powyższej badanej wskazuje na to, że przygotowywanie się do pracy odbywa się również poza godzinami pracy i poza ośrodkiem, kiedy pracownice są w swoich domach. Gdy usłyszą policję, pogotowie czy straż, komunikują się już ze sobą i zastanawiają, czy doszło do jakiegoś wydarzenia na ich terenie. Ale o ile pracę biurową można zaplanować i przewidzieć, to sytuacja jest nieco trudniejsza w przypadku pracy w terenie.

Praca w terenie składa się z interwencji lub wywiadów środowiskowych. Interwencje to niezaplanowane wyjazdy ankietowanych w teren, najczęściej poprzedzone telefonem od rodziny czy sąsiadów, że w danym miejscu jest potrzebny pracownik socjalny. Na tego rodzaju pracę nie można się odpowiednio przygotować, po prostu nie ma czasu na działania za kulisami. Sytuacje zazwyczaj są spontaniczne i nagłe. Główną rolę odgrywa tutaj czas i pracownik nie może sobie pozwolić na odłożenie w czasie wyjazdu na interwencję:

Badaczka: Czy przygotowujesz się do pracy w terenie?

B2: Nie, wszystkie działania są spontaniczne. Mamy interwencję, coś się dzieje, więc wsiadamy w auto i jedziemy, żeby się przygotować to ciężko, bo nie wiemy co zastaniemy na miejscu. Każda sytuacja jest inna, czegoś innego dotyczy i tak naprawdę to dopiero na miejscu po rozeznaniu się w sytuacji, jak ona wygląda, czego dotyczy, możemy podjąć jakieś kroki, na przykład często decydujemy się na wezwanie policji czy jeszcze jakieś nie wiem inne decyzje się podejmuje, ale to tak jak mówię zależy czego dana sytuacja dotyczy.

Dopiero po wkroczeniu na scenę, czyli na miejsce zdarzenia, do którego zostali wezwani, aktorzy dobierają środki potrzebne do wypełnienia roli pracownika socjalnego i udzielenia pomocy oraz decydują się na zaproszenie do udziału w występie innych aktorów, czyli na przykład policji.

Wywiady środowiskowe są tymi działaniami, do których pracownik socjalny może się odpowiednio przygotować, a nawet musi, aby nie tracić czasu. Pracownicy socjalni, którzy pracują w terenie, ustalają comiesięczne plany wizyt w rodzinach, które mają pod swoją opieką (wizyty odbywają się zawsze w te same dni), następnie kompletują odpowiednią dokumentację, ustalają trasę przebiegu i wyruszają w teren: 
Badaczka: Czy przygotowujesz się do pracy w terenie?

B3: Tak, jak mamy te objazdówki to zawsze mamy ustaloną trasę, w którą stronę jedziemy i wtedy bierzemy wywiady do tych rodzin, do których jedziemy. No i przygotowujemy się, żeby nie kręcić się w kółko tylko, żeby jakoś logicznie tę trasę ułożyć.

Na to samo pytanie badaczki zostały udzielone dwie skrajne odpowiedzi. Wynika to z faktu, iż pierwsza z pracownic nie przeprowadza wywiadów środowiskowych. Z reguły pracuje w ośrodku, a czasami zdarza się, że bierze udział w interwencjach. Natomiast druga ankietowana pracownica socjalna biorąca udział w badaniu pracuje w terenie i na co dzień przeprowadza wywiady środowiskowe z podopiecznymi. Reasumując wątek kulis, uważam, że to tam dochodzi do rozgrywek w wielu różnych sytuacjach i to, co się tam dzieje, decyduje o tym, czy występ będzie udany.

\section{Występy - pojawianie się na wielu scenach}

Kształtując rolę pracownika socjalnego, aktorzy nieustannie biorą udział w występach, a jednocześnie pojawiają się na wielu scenach. Pierwszą scenę, której nie można uniknąć i na której dochodzi do niewątpliwie przełomowego momentu, jest praktyka, stająca się wcześniej czy później kulisami. Badane zgodnie przyznały, że jest to pierwsze zetknięcie z pomocą społeczną i wówczas następuje weryfikacja, czy chcemy wyjść na kolejną scenę, czyli do pracy. To właśnie podczas praktyk student ma okazję wykorzystać wiedzę nabytą podczas studiów oraz pierwszy raz wcielić się w rolę pracownika socjalnego i uczestniczyć w pracy w terenie razem z pracownikiem socjalnym:

W trakcie praktyk gdzieś tam pojawiały się różne komentarze typu „No ja siebie widzę w tym i w tym, ja bym chciała to i tamto", gdzieś tam od razu było widać, komu jakie przedmioty, jakie praktyki bardziej leżą, bardziej pasują, niż mniej. Ale raczej wszyscy gdzieś tam szukali sobie własnych idei. Były osoby, które powiedziały, że one nie chcą mieć nic wspólnego już potem z pracą socjalną. A na przykład okazało się, że jednak pracują jako pracownicy socjalni aktualnie (śmiech). No były też takie osoby, które się odcięły totalnie (...) (B6).

Kolejna scena, na której odgrywana jest społeczna rola pracownika socjalnego, to miejsce ich pracy, czyli ośrodek lub praca w terenie. W przypadku pracy na miejscu, w ośrodku, to głównie przyjmowanie petentów oraz wniosków od nich, ale również sporo innej pracy, ponieważ program socjalny ciągle się rozwija i zawiera coraz większą liczbę elementów. Pracownicy socjalni oprócz udzielania wsparcia potrzebującym piszą również projekty oraz zajmują się umieszczaniem osób w różnych placówkach. Wykonują wiele zadań, które są niewidoczne dla publiczności:

Generalnie obowiązków mamy coraz więcej, bo nasz program socjalny ciągle się rozwija. My oprócz tego, że świadczymy pomoc społeczną, czyli różnorakie wsparcie naszym osobom to też piszemy projekty unijne, które później musimy realizować, pozyskiwać środki, więc to jest cała 
masa rzeczy, bo to nie jest tylko praca socjalna, czyli przyjęcie wniosku, zrobienie wywiadu i wydanie decyzji. Ale też jest umieszczanie ludzi w Domach Opieki Społecznej, w schroniskach, monitorowanie ludzi, którzy są samotni, a trafiają do szpitala i zostawieni są bez jakiejkolwiek pomocy, to są zwykłe problemy rodzinne, to jest zespół interdyscyplinarny, to są seniorzy, których też trzeba objąć wsparciem (B3).

Występy w terenie mają pewien zaplanowany przebieg, scenariusz wywiadów jest ustalony wcześniej, pracownicy znają go, dzięki czemu występ ten postrzegany jest jako przewidywalny i kontrolowany. Sceną staje się wówczas miejsce zamieszkania petenta, w którym przeprowadzony zostaje wywiad środowiskowy. Pracownik socjalny musi iść do domu petenta wraz z kompletem dokumentów, które należy wypełnić:

(...) udajemy się w teren, wywiad środowiskowy musi być przeprowadzony w miejscu zamieszkania, czyli u osoby, która korzysta ze wsparcia, taka osoba, żeby otrzymać taką pomoc musi nam otworzyć drzwi, musi nam umożliwić przeprowadzenie wywiadu (...) (B2).

Jeśli istnieje taka potrzeba to pracownicy socjalni oprócz przeprowadzania wywiadów oraz prac biurowych, zobligowani są również do wykonania czynności związanych z organizacją życia swoich petentów, na przykład pomagają w załatwieniu różnych spraw. Czasami pomagają skompletować dokumentację, wypełnić wnioski, załatwić sprawy w urzędzie. Dzięki legitymacji pracowniczej mogą zrobić to bez oczekiwania w kolejce. Dlatego często też się zdarza, że sceną, na której muszą odgrywać swoją rolę, jest sklep, przychodnia lekarska, szpital, sąd, szkoła, urząd gminy:

Często gęsto pomagamy ludziom zdobyć jakieś zaświadczenie, kompletujemy ich dokumentację medyczną, dajemy im wszystkie wnioski, które potrzebne są do lekarza, a później pomagamy im je złożyć jeszcze, żeby starać się o stopień niepełnosprawności (B2).

Mamy na przykład możliwość w ramach wykonywania obowiązków służbowych w urzędach załatwiać sprawy petentów bez kolejki, czyli jak idziemy w sprawie petenta do lekarza czy urzędu, czy gdzieś to możemy się wylegitymować i bez kolejki załatwić sprawę (B3).

Kształtowanie i odgrywanie społecznej roli pracownika socjalnego rozciąga się na różne sytuacje, także takie poza ośrodkiem i poza wizytami terenowymi, kiedy pracownik w ramach swoich obowiązków załatwia sprawy swoich petentów. Pracownik socjalny nie może przewidzieć, kiedy i na jakiej scenie będzie musiał odgrywać rolę.

\section{Wnioski}

Przeprowadzona analiza danych z wywiadów pogłębionych oraz obserwacji uczestniczących pozwoliła stwierdzić, że społeczna rola pracowników socjalnych jest kształtowana wraz z wchodzeniem w kolejne interakcje z innymi aktorami oraz podczas występów 
na scenie. Od tych z wykładowcami i studentami na etapie studiów, przez interakcje z pracownikami socjalnymi na etapie praktyk i staży, po wchodzenie w sytuacje zawodowe podczas wykonywania zawodu pracownika socjalnego. Aby móc wcielić się w rolę aktora - pracownika socjalnego, należy posiadać pewien zestaw cech, które ułatwią odgrywanie tejże roli, na przykład opiekuńczość i empatia. Chociaż według respondentek płeć nie ma znaczenia w wykonywaniu zawodu pracownika socjalnego, to w tę rolę zdecydowanie częściej wcielają się kobiety. Aby występ był udany, aktor powinien przygotować się do niego w miejscu zwanym kulisami. Kulisami mogą być studia, praktyki zawodowe lub miejsce pracy. To od kulis zależy, czy występ będzie udany czy też nie. Definicji sytuacji, w której się znajdujemy, dostarcza nam fasada, na którą składają się fasada osobista oraz dekoracje. Fasada osobista to na przykład cechy charakteru czy nawet cechy demograficzne, które określają danego pracownika socjalnego, jak bycie kobietą. Natomiast w skład dekoracji wchodzą wszystkie elementy, które można zauważyć na scenie, jest to na przykład Ustawa o pomocy społecznej. W trakcie występów aktorzy biorą udział w kilku procesach, takich jak zaufanie do roli, dramatyzacja działalności, idealizacja, kontrolowanie ekspresji, fałszywa prezentacja, mistyfikacja, rzeczywistość i gra. W ramach wspomnianych procesów to aktorzy sami decydują, jakie wrażenie będą chcieli wywrzeć na publiczności. Ważnym elementem koncepcji dramaturgicznej są scenariusze, które pomagają w odgrywaniu swojej roli. Jednak nie ma jednego, odpowiedniego dla wszystkich scenariusza, jak przygotować się do roli pracownika socjalnego. Na podstawie przeprowadzonej analizy stwierdzam, że społeczna rola pracowników socjalnych jest kształtowana w czasie interakcji z innymi aktorami oraz odgrywana w czasie występów z ustalonym porządkiem interakcyjnym.

Podjęty temat jest dla mnie ważny, ponieważ kiedyś rozważałam studiowanie pracy socjalnej. Dlatego wybrałam realizację praktyk zawodowych w Gminnym Ośrodku Pomocy Społecznej. Dzięki odbytym praktykom mogłam poszerzyć swoją wiedzę na temat pomocy społecznej. Z przeprowadzonych badań wynika, że wykonywanie zawodu pracownika socjalnego jest pracą trudną i nieprzewidywalną, momentami niebezpieczną. Godziny pracy są nienormowane, ponieważ pracownik socjalny musi być przez większość czasu pod telefonem i w każdej chwili może zostać wezwany na interwencję. To bardzo potrzebny zawód, ponieważ - jak same pracownice socjalne stwierdziły - problemów społecznych jest coraz więcej. Myślę, że materiał przedstawiony w tekście może być interesujący dla każdej osoby interesującej się pracą socjalną lub myślącej o studiowaniu tego kierunku. Uważam, że moje badania można kontynuować, poszerzając próbę przez włączenie do niej mężczyzn. 


\section{Bibliografia}

Flick U. (2010). Projektowanie badania jakościowego. Niezbędnik badacza, tłum. P. Tomanek. Wydawnictwo Naukowe PWN, Warszawa.

Goffman E. (1981). Człowiek w teatrze życia codziennego, tłum. H i P. Śpiewakowie. Państwowy Instytut Wydawniczy, Warszawa. 